\title{
PEMAKAIAN KONTRASEPSI SUNTIK AKAN MEMPENGARUHI BERAT BADAN AKSEPTOR KB SUNTIK DI KOTA BARU DRIYOREJO
}

\author{
Nurul Kamariyah \\ UNUSA, FKK, Prodi SI Keperawatan, Jl. Smea 57 Surabaya \\ Email : nurulkamariyah@unusa.ac.id
}

\begin{abstract}
Acceptor use of contraceptive injection most complain weight increased. Although knowing acceptor increased weight, they keep use contraceptive injectable. Therefore, this study was purposed to find out the correlation between the use of contraceptive injection and the body weight change happening to the acceptors. The design of study was analytic-cross sectional. The population involved all acceptors using contraceptive injection for more than one year,totally 89 people. 74 respondents were chosen as the samples by using probability sampling in which the simple random sampling technique was applied in this study. Variable of this research are independent (the use of contraceptive injection) and dependent (the body weight change). The data were collected by using family planning registration card, observation sheets, and a weight scale. The data were processed by editing, coding and tabulating. The data analysis was done by using Mann-Whitney's test with the significance level $\alpha=0.05$. The result of analysis showed that $p=0.007<\alpha=0.05$ which meant that $H_{0}$ was rejected most of the acceptors having three-month contraceptive injection had weight gain. describing that there was a correlation between the use of contraceptive injection and the body weight change happening to the acceptors. The conclusion of this study was that the use of contraceptive injection containing hormone affect the change of body weight. Thus, the correct counseling, information, and education to the acceptors contraceptive injection to choice non hormonal contraceptive if experienced excessive weight gain.
\end{abstract}

ABSTRAK : Akseptor yang menggunakan KB suntik sebagian besar mengeluh berat badannya meningkat. Walaupun akseptor mengetahui berat badan meningkat, mereka tetap memakai kontrasepsi suntik. Tujuan penelitian untuk mengetahui hubungan pemakaian KB suntik dengan perubahan berat badan pada akseptor KB suntik. Jenis penelitian ini adalah analitik dengan rancang bangun cross sectional. Populasi semua akseptor KB suntik yang telah mengikuti kontrasepsi suntik $>1$ tahun, sebesar 89 responden, sampel sebesar 74 responden diambil secara probability sampling dengan tehnik simple random sampling. Variabel indepen pemakaian KB suntik dan variabel independen berat badan. Pengumpulan data menggunakan kartu register KB, lembar observasi, penimbangan BB. Pengolahan data dengan cara Editing, Coding, Tabulating. Analisa data dengan menggunakan uji mann-whitney dengan tingkat kemaknaan $\alpha=$ 0,05. Hasil penelitian di dapatkan nilai $\mathrm{p}=0,007 \alpha=0,05$ berarti $\mathrm{p}<\alpha$ maka Ho ditolak artinya ada hubungan antara pemakaian kontrasepsi suntik dengan berat badan. Simpulan dari penelitian ini adalah pemakaian KB suntik yang mengandung hormon dapat mempengaruhi perubahan berat badan. KIE yang baik terhadap akseptor KB suntik untuk melakukan pengaturan makan jika menggunakan kontrasepsi suntik.

Kata kunci : KB suntik, berat badan. 


\section{PENDAHULUAN}

Program KB nasional mempunyai arti penting dalam pelaksanaan pembangunan di bidang kependudukan dan keluarga kecil berkualitas yang dilaksanakan secara berkesinambungan (BKKBN,2005). Visi program Keluarga berencana adalah membentuk keluarga berkualitas 2015 untuk mewujudkan penduduk yang berkualitas dimana keluarga menjadi maju, mandiri, sejahtera, dalam kehidupan yang serasi, selaras dan seimbang dengan daya dukung dan daya tampung lingkungan melalui keluarga kecil sebagai bagian yang mutlak untuk peningkatan kualitas sumber daya manusia yang potensial bagi pembangunan nasional, maka pemerintah lebih banyak berinisiatif untuk peningkatan peran serta masyarakat dalam menanggulangi masalah kependudukan dengan penggunaan alat kontrasepsi yang merupakan salah satu langkah efektif untuk menunda kehamilan (BKKBN, 2009).

Saat ini tersedia banyak metode atau alat kontrasepsi meliputi IUD, suntik, pil, implant, kontap, kondom. Salah satu kontrasepsi yang populer di Indonesia adalah kontrasepsi suntik. Sebagian ibu yang menggunakan KB suntik 1 bulan dan 3 bulan di BPS Zulchoiliyah Surabaya mengeluh berat badan dan nafsu makan mereka meningkat. Walaupun akseptor mengetahui berat badan mereka meningkat, akan tetapi mereka tetap memakai kontrasepsi suntik. Kontrasepsi suntik yang digunakan adalah Noretisteron Enantat (NETEN), Depo Medroksi Progesteron Acetat (DMPA) dan cyclofem (Sarwono,2006). Pada tahun 2012 tercatat jumlah peserta KB aktif dari 64.133.347 juta jiwa, dengan jumlah PUS 161.750.743 juta jiwa dan WUS 51.472.069 juta jiwa.Dari 64.133.347 peserta KB aktif, pengguna $\mathrm{KB}$ suntik $(54,35 \%)$, peserta pil $(28,65 \%)$, peserta IUD $(5,44 \%)$, peserta kondom $(5,34 \%)$, peserta implant $(4,99 \%)$, peserta MOW $(1,04 \%)$ dan peserta MOP $(0,2 \%)$. (Kemenkes RI, 2010)
Berdasarkan data yang didapat tahun 2014 di perumahan Kota Baru Driyorejo dari 10 orang yang menggunakan kontrasepsi suntik sebagian besar $(70 \%)$ mengalami kenaikan berat badan. Total PUS yang menjadi peserta KB aktif sebanyak 232 orang. Peserta KB aktif tersebut menggunakan kontrasepsi suntik 3 bulan $112(36,5 \%)$, suntik 1 bulan 87 $(55,1 \%)$, pil $24(7,5 \%)$, implant 1 $(0,6 \%)$, IUD $5(0,6 \%)$.

Berdasarkan hasil penelitian sebelumnya dihasilkan bahwa akseptor yang menggunakan kontrasepsi KB suntik satu bulan mengalami kenaikan berat badan yang paling banyak dan akseptor KB suntik tiga bulan mengalami kenaikan berat badan sedikit, padahal kandungan hormon progesteron paling banyak terdapat di dalam KB suntik tiga bulan. Adanya hormon progesteron merangsang hormon nafsu makan yang ada di hipotalamus. Dalam hal ini berarti bukan hanya hormon progesteron yang dapat mempengaruhi perubahan berat badan. Akan tetapi pada dasarnya perubahan berat badan dipengaruhi oleh beberapa faktor.

Secara umum faktor-faktor yang dapat mempengaruhi perubahan berat badan dapat dibagi atas dua golongan besar yaitu faktor intern yang terbagi atas 3 bagian yakni usia, kejiwaan, hereditas. Dan faktor ekstern yang meliputi makanan, lingkungan fisik (Bindiknakes, 2001). Dengan adanya nafsu makan yang lebih banyak dari biasanya tubuh akan kelebihan zat-zat gizi. Kelebihanzat-zat gizi oleh hormon progesteron dirubah menjadi lemak dan disimpan di bawah kulit. Perubahan berat badan ini akibat adanya penumpukan lemak yang berlebih hasil sintesa dari karbohidrat menjadi lemak. Pertambahan berat badan 1,5 - $2 \mathrm{~kg}$ dan berat badan pada kunjungan pertama (Mansjoer, 2003). Pertambahan berat 
badan disebabkan oleh retensi cairan, bertambah nya lemak pada tubuh, dan meningkatkan selera makan (Hartanto, 2004). Sedangkan pemakaian cyclofem berat badan meningkat rata-rata dua hingga tiga kilogram tahun pertama pemakaian, dan terus bertambah selama tahun kedua(Varney, 2007).

Perubahan berat badan yang terlalu mencolok dapat mengakibatkan beberapa gangguan kesehatan diantaranya peningkatan resiko penyakit jantung, stroke, diabetes dan obesitas. Upaya yang perlu dilakukan petugas kesehatan yaitu memberikan KIE (komunikasi, informasi serta edukasi) tentang penyebab terjadinya, dan anjurkan klien untuk melakukan diet rendah kalori serta olah raga secara teratur. Bila cara tersebut tidak dapat membantu dan berat badan makin bertambah maka pemakaian suntikan dihentikan dan disarankan untuk ganti jenis kontrasepsi lain yang non hormonal. Apabila klien mengeluh berat badan nya menurun anjurkan untuk diet tinggi protein dan kalori serta pastikan penurunan berat badan ini bukan karena penyakit kronis (SMPFA, 2002).

\section{METODE}

Rancang bangun adalah analitik dengan pendekatan cross sectional yakni dengan mengetahui hubungan pemakaian kontrasepsi suntik dengan berat badan pada akseptor suntik di waktu yang sama. Populasi semua akseptor suntik di wilayah kerja puskesmas Kota Baru Driyorejo (KBD) yang telah mengikuti suntik > 1 tahun, sebesar 89 orang, sampel adalah sebagian akseptor kontrasepsi suntik > 1 tahun.di KBD dengan kriteria sampel yaitu akseptor yang sudah mengikuti KB suntik. Adapun besar sampel dalam penelitian ini ditetapkan berdasarkan rumus sebesar 74 responden. Sampling di lakukan secara probability sampling, dengan tehnik simple random sampling yaitu setiap subyek dalam populasi mempunyai kesempatan untuk terpilih dan tidak terpilih sebagai sampel dan diseleksi secara random (acak). Variabel independen (variabel bebas) adalah pemakaian kontrasepsi suntik dan variabel dependen dalam penelitian ini adalah berat badan. Instrumen dalam penelitian ini menggunakan kartu register $\mathrm{KB}$, lembar observasi dan alat timbang berat badan. Teknik pengumpulan data dengan data primer diperoleh melalui quisioner tentang berat badan sebelummengikuti kontrasepsi suntik, dan penimbanganberat badan saat penelitian. sedangkan klarifikasi didapat daridata sekunder diperoleh dari kartu register penggunaan kontrasepsi adapun data yang peneliti butuhkan adalah berat badan akseptor sebelum menggunakan KB suntik. Pengolahan data editing, Coding, Tabulating, untuk mengetahui hubungan pemakaian kontrasepsi suntik dengan berat badan pada akseptor KB suntik dengan Uji Mann-Whitney dengan menggunakan program SPSS for windows dengan tingkat kemaknaan $\alpha=$ 0,05. Dimana Ho ditolak apabila $\mathrm{p}<\alpha$ $(0,05)$ yang berarti ada hubungan antara pemakaian KB suntik dengan perubahan berat badan pada akseptor KB suntik . Sebaliknya $\mathrm{H}_{0}$ diterima apabila $\mathrm{p}>\alpha$ $(0,05)$ yang berarti tidak ada hubungan antara antara pemakaian KB suntik dengan perubahan berat badan pada akseptor KB suntik di Kota Baru Driyorejo (KBD).

\section{HASIL}

1. Data Umum

Berikut ini akan disajikan tentang data umum yang meliputi umur dan lama pemakaian menggunakan $\mathrm{KB}$ suntik.

a. Karakteristik responden berdasarkan Umur

Tabel 5.1 Distribusi frekuensi menurut umur responden di KBD Gresik bulan Juni tahun 2013

\begin{tabular}{|c|c|c|c|}
\hline$N_{3}$ & 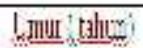 & meduews & linewasts \\
\hline 1. & $<1$ & 2 & 17 \\
\hline i. & 21.33 & 56 & $7 \%$ \\
\hline 3 & $>35$ & b3 & 176 \\
\hline & J-mih & 74 & 109 \\
\hline
\end{tabular}


Tabel 5.1 menunjukkan bahwa dari 74 responden hampir seluruhnya $(82,4 \%)$ adalah masa reproduksi (berumur 20-35 tahun)

b. Karakteristik responden berdasarkan Lama pemakaian KB suntik

Tabel 5.2 Distribusi frekuensi responden menurut lama pemakaian di KBD Gresik bulan Juni tahun 2013

\begin{tabular}{|c|c|c|c|}
\hline$N_{3}$ & Lana Pewaxiac & 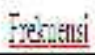 & Pesertas $(x)$ \\
\hline 1. & $<$ thlus & 45 & 59,8 \\
\hline 2 & 22 ladu: & 29 & $3: 2$ \\
\hline & Jumla & 77 & if \\
\hline
\end{tabular}

Tabel 5.2 menunjukkan bahwa dari 74 responden sebagian besar $(60,8 \%)$ lama pemakaian KB suntik adalah $<2$ tahun.

\section{Data khusus}

Berikut ini akan disajikan tentang data khusus yang meliputi jenis KB suntik dan perubahan berat badan KB suntik.

a. Karakteristik responden berdasarkan jenis KB suntik

Tabel 5.3 Distribusi frekuensi responden menurut jenis kontrasepsi suntik di KBD Gresik bulan Juni tahun 2013

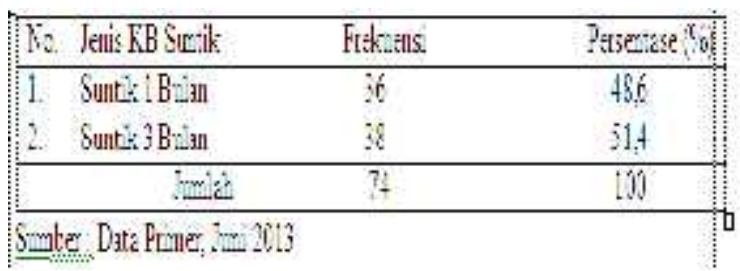

Tabel 5.3 menunjukkan bahwa dari 74 responden sebagian besar $(51,4 \%)$ jenis KB suntik adalah Suntik 3 bulan.

b. Karakteristik responden berdasarkan perubahan berat badan

Tabel 5.4 Distribusi frekuensi responden menurut perubahan berat badan suntik di KBD bulan Juni tahun 2013

\begin{tabular}{|c|c|c|}
\hline Yo. Ferubatian Ber Dacs= & Freku=si & Pextriast $x h$ \\
\hline Tera & 19 & 25.7 \\
\hline Trtip & .7 & 23,0 \\
\hline Nik: & 38 & 314 \\
\hline 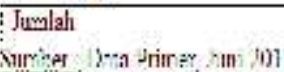 & 74 & 109 \\
\hline
\end{tabular}

Tabel 5.4 menunjukkan bahwa dari 74 responden sebagian besar $(51,4 \%)$ perubahan berat badan adalah mengalami kenaikan berat badan.

c. Tabulasi silang pemakaian KB suntik terhadap perubahan berat badan pada akseptor KB suntik.

Tabulasi silang yang merupakan karakteristik responden menurut akseptor KB suntik dengan perubahan berat badan dapat di jelaskan pada tabel berikut.

Tabel 5.5 Tabulasi silang akseptor KB suntik dengan perubahan berat badan di KBD Gresik bulan Juni tahun 2013

\begin{tabular}{|c|c|c|c|c|}
\hline \multirow{2}{*}{ 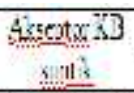 } & \multicolumn{4}{|c|}{$P_{n-1}=3 R$} \\
\hline & Zur:n $x^{x}(0)$ & 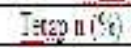 & $\mathrm{N} 2 ; \mathrm{n}^{*} \mathrm{l}$ & Jmlin a $(\mathrm{c} t)$ \\
\hline Suntik 1 mulan & $(5+1,7)$ & $7(9,4)$ & $(4,389)$ & 35000 \\
\hline Suntik : sulan & $+(0,5)$ & {$[1,25,3\}$} & $24(69)$ & $38(10)$ \\
\hline ctil & (1) $(2,2)$ & $2-29$ & $3601-1$ & $(+1.19)$ \\
\hline
\end{tabular}

Berdasarkan Tabel 5.5 menunjukan bahwa 36 akseptor KB suntik 1 bulan hampir setengah $(41,7 \%)$ mengalami penurunan berat badan. Sedangkan dari 38 akseptor KB suntik 3 bulan sebagian besar $(63,2 \%)$ mengalami kenaikan berat badan.

Berdasarkan uji statistik MannWhitney dengan tingkat kemaknaan $\alpha=$ 0,05 . Setelah dilakukan uji didapatkan hasil $\mathrm{p}=0,007$, artinya $\mathrm{p}<\alpha$ maka Ho ditolak berarti ada hubungan antara pemakaian KB suntik dengan perubahan berat badan pada akseptor KB suntik di KBD Gresik.

d. Karakteristik responden menurut rata-rata perubahan berat badan

Karakteristik responden menurut rata-rata perubahan berat badan dapat dijelaskan pada tabel berikut.

Tabel 5.6 Distribusi frekuensi responden menurut ratarata perubahan berat 
badan di KBD Gresik bulan Juni tahun 2013

\begin{tabular}{|c|c|c|}
\hline \multirow{3}{*}{$\begin{array}{l}\text { kJ saris } \\
\text { Sur is is inl }\end{array}$} & \multicolumn{2}{|c|}{ Kret } \\
\hline & 5 & Tita: \\
\hline & $3.5^{\circ}$ & $2 \pi$ \\
\hline Suc is 3 yul & 3,2 & 1.7 \\
\hline
\end{tabular}

Berdasarkan tabel 5.6 dapat diketahui bahwa rata-rata kenaikan berat badan akseptor KB suntik 1 bulan adalah $2,5 \mathrm{~kg}$ dan rata-rata penurunan berat badan akseptor KB suntik 1 bulan adalah 2,0 kg . Sedangkan rata-rata kenaikan berat badan akseptor KB suntik 3 bulan adalah $3,2 \mathrm{~kg}$ dan rata-rata penurunan berat badan akseptor suntik KB suntik 3 bulan adalah $1,7 \mathrm{~kg}$.

\section{PEMBAHASAN}

1. Pemakaian KB suntik terhadap perubahan berat badan

Berdasarkan tabel 5.3 menunjukkan bahwa dari 74 responden sebagian besar $(51,4 \%)$ jenis $\mathrm{KB}$ suntik adalah suntik 3 bulan karena akseptor hanya disuntik $4 \mathrm{x}$ dalam setahun dan sangat menguntungkan bagi akseptor yang tidak suka terlalu sering disuntik. Sesuai dengan pendapat Wiknjosatro (2011) yang mengatakan bahwa keuntungan kontrasepsi suntikan berupa depo ialah : efektivitas tinggi, pemakaiannya sederhana, cukup menyenangkan bagi akseptor (injeksi hanya $4 \mathrm{x}$ setahun), reversible dan cocok bagi ibu yang menyusui anak.

Berdasarkan tabel 5.1 menunjukkan bahwa dari 74 responden hampir seluruhnya $(82,4 \%)$ adalah berusia $20-35$ tahun (masa reproduksi) dikarenakan dalam masa reproduksi ini hormon dalam tubuh wanita meningkat. Hal ini sesuai dengan pendapat Wiknjosastro (2011) bahwa salah satu indikasi dari pemakaian suntik 1 bulan adalah wanita pada usia reproduksi dan ini dapat mengakibatkan penambahan berat badan karena pada usia reproduksi tersebut kandungan dari alat kontrasepsi 1 bulan yaitu hormon esterogen dan progesteron meningkat sehingga dapat mengakibatkan nafsu makan bertambah.

2. Perubahan berat badan akseptor KB suntik

Lama pemakaian juga mempengaruhi perubahan berat badan berdasarkan tabel 5.2 menunjukkan bahwa dari 74 responden sebagian besar $(60,8 \%)$ lama pemakaian KB suntik adalah < 2 tahun. Lama pemakaian mempengaruhi perubahan berat badan seseorang semakin lama seseorang menggunakan KB suntik maka perubahan berat badannya akan terlihat mencolok. Lama pemakaian juga mempengaruhi perubahan berat badan sesuai dengan pendapat Saifuddin (2003) bahwa pemakaian alat kontrasepsi suntik 1 bulan dengan penggunaan jangka panjang akan menyebabkan perubahan atau peningkatan berat badan.

Berdasarkan tabel 5.4 menunjukkan bahwa dari 74 responden sebagian besar $(51,4 \%)$ perubahan berat badan adalah mengalami kenaikan. Perubahan berat badan ini dikarenakan adanya hormon progesteron. Demikian pula dengan pendapat (Mansjoer, 2003) Faktor yang mempengaruhi perubahan berat badan akseptor KB suntik adalah adanya hormon progesteron yang kuat sehingga merangsang hormon nafsu makan yang ada di hipotalamus. Dengan adanya nafsu makan yang lebih banyak dari biasanya tubuh akan kelebihan zat-zat gizi. Kelebihan zat-zat gizi oleh hormon progesteron dirubah menjadi lemak dan disimpan di bawah kulit. Perubahan berat badan ini akibat adanya penumpukan lemak yang berlebih hasil sintesa dari karbohidrat menjadi lemak.

Akan tetapi selain faktor internal yaitu hormon yang dapat mempengaruhi perubahan berat badan seseorang ada juga faktor eksternal seperti makanan, karena semakin banyak seseorang makan maka akan terjadi peningkatan 
berat badan sebaliknya jika seseorang semakin sedikit makan maka akan terjadi penurunan berat badan. Fisik seseorang juga mempengaruhi terhadap perubahan berat badan karena aktifitas fisik yang berlebihan akan membuat seseorang kelebihan energi yang dapat membakar lemak tubuh, sebaliknya jika aktifitas fisik berkurang maka akan terjadi penumpukan lemak dalam tubuh. Faktor umur mempengaruhi perubahan berat badan karena dengan bertambahnya umur energi yang dikeluarkan menurun. Faktor sosial ekonomi juga mempengaruhi perubahan berat badan karena pemicunya adalah meningkatnya kemakmuran yang menyebabkan gaya hidup dan pola makan berubah sementara pertumbuhan dikota besar dengan ruang terbuka yang minim menyebabkan orang menjadi kurang bergerak ditambah lagi dengan kemajuan teknologi orang lebih banyak menghabiskan waktu didepan komputer atau televisi. Dan perubahan jenis makanan dari yang "tradisional" beralih kemakanan siap saji yang lebih banyak lemak, rendah serat dan tinggi kalori daripada sayuran dan buah-buahan. Hal ini sesuai dengan yang dikemukakan Depkes RI (2001) bahwa faktor-faktor lain yang mempengaruhi penambahan berat badan yaitu faktor umur, olahraga, faktor genetik, dan faktor sosial ekonomi. Sedangkan faktor yang mempengaruhi penurunan berat badan di mungkinkan pola makan, kepekaan terhadap penyakit, lingkungan, emosional, dan diet. Namun, hal itu juga bergantung pada faktor genetik pada masing-masing akseptor suntik.

3. Hubungan Antara Pemakaian KB Suntik Dengan Perubahan Berat Badan Pada Akseptor KB Suntik.

Berdasarkan tabel 5.3 menunjukkan bahwa dari 74 responden sebagian besar $(51,4 \%)$ jenis KB suntik adalah Suntik 3 bulan dan berdasarkan tabel 5.4 menunjukkan bahwa dari 74 responden sebagian besar $(51,4 \%)$ perubahan berat badan adalah mengalami kenaikan berat badan. Kemudian dianalisis dengan menggunakan SPSS 16.0 For Windows dengan uji Mann-Whitney dengan tingkat kemaknaan $(\alpha=0,05)$ Setelah dilakukan uji didapatkan hasil $\mathrm{p}=$ 0,007, artinya $\mathrm{p}<\alpha$ maka Ho ditolak berarti ada hubungan antara Pemakaian KB Suntik dengan perubahan berat badan pada akseptor kontrasepsi suntik di KBD Gresik. Pemakaian kontrasepsi suntik mempengaruhi perubahan berat badan dikarenakan adanya hormon estrogen yg menyebabkan kenaikan berat badan dan hormon progeteron yang menyebabkan nafsu makan bertambah.

Hasil penelitian diatas dapat dijelaskan bahwa selain faktor internal yaitu hormon, faktor ekternal juga mempengaruhi perubahan berat badan Hal ini sesuai dengan yang dikemukakan Depkes RI (2001) bahwa faktor-faktor lain yang mempengaruhi penambahan berat badan yaitu faktor umur, olahraga, faktor genetik, dan faktor sosial ekonomi. Sedangkan faktor yang mempengaruhi penurunan berat badan di mungkinkan pola makan, kepekaan terhadap penyakit, lingkungan, emosional, dan diet. Namun, hal itu juga bergantung pada faktor genetik pada masing-masing akseptor suntik.

\section{SIMPULAN}

Berdasarkan hasil penelitian dan pembahasan mengenai hubungan pemakaian KB suntik dengan perubahan berat badan pada akseptor KB suntik di KBD Gresik, maka dapat disimpulkan sebagai berikut :

a. Pemakaian kontrasepsi suntik di KBD Gresik sebagaian besar adalah menggunakan kontrasepsi suntik 3 bulan.

b. Perubahan berat badan akseptor kontrasepsi suntik di KBD Gresik 
sebagian besar mengalami kenaikan berat badan.

c. Ada hubungan antara pemakaian KB suntik dengan perubahan berat badan pada akseptor KB suntik di KBD Gresik.

\section{DAFTAR PUSTAKA}

Binadiknakes, (2001).Elektromedik dan pengembangannya. Edisi No 17

BKKBN, (2002). Informasi Pelayanan Kontrasepsi. Jakarta: BKKBN.

BKKBN, (2005).Unit Pelayanan Kontrasepsi. Jakarta: BKKBN

BKKBN,(2009).Keluarga Berencana dan Kesehatan Reproduksi: Kebijakan Program dan Kegiatan tahun 20052009. Jakarta: BKKBN.

BKKBN,(1991).Buku materi pelatihan pelayanan kontrasepsi efektif terpilih untuk tenaga pplkb dan plkb. Jakarta: BKKBN

Centroone.(2012).Peserta KB Terus Meningkat. http://centroone.com. Diakses tanggal 1 Maret 2013.

Cucuhawa(2012). Proposal kti.http://cucu hawa. blogspot.com.Diakses tanggal 2 Maret 2013

Constance, (2009). Buku Saku Kebidanan. Jakarta. EGC.
Depkes, (2001). Pedoman Penanggulangan Efek Samping/Komplikasi Kontrasepsi, Jakarta:Depkes RI

Erna Lusiana,(2012) kata-kata mutiara. http://erna lusiana. blogspot.com. Diakses tanggal 2 Maret 2013 lusiana.

Hartanto,(2004).Keluarga Berencana dan Kontrasepsi. Jakarta: Pustaka Sinar Harapan.

Mansjoer.(2003). Kapita Selekta Kedokteran Jilid 2 Edisi 3. Jakarta: Fakultas Kedokteran Universitas Indoensia.

Manuaba, (2010).Ilmu Kebidanan, Penyakit Kandungan dan Keluarga Berencana. Jakarta: EGC

Mochtar, Rustam.(1998). Sinopsis Obstetri Jilid 2 edisi 2.Jakarta : EGC
Philips, (2004).Generasi muda semakin tambur.www. Geocities.com. 2002.

Saifudin, (2003).Buku Panduan Praktis Pelayanan Kontrasepsi. Jakarta: Yayasan

Bina Pustaka Sarwono Prawirohardjo. SMPFA,(2002).Pedoman Penanggulangan Efek Samping Atau Komplikasi Kontrasepsi. Prop. Jatim.

Supariasa, (2003). Penilaian Status Gizi. Jakarta: EGC

Suparyanto(2010).Pengaruh KB Suntik terhadap Perubahan Berat Badan.http://suparyanto.blogspot. com. Diakses tanggal 5 April 2013.

Varney, 2007. Buku Ajar Asuhan Kebidanan edisi 4. Jakarta: EGC.

Wiknjosastro, (2011).IlmuKebidanan. Jakarta: Yayasan Bina Pustaka Sarwono Prawirohardjo. 